\title{
Peningkatan hasil belajar tolak peluru melalui penerapan strategi pembelajaran resiprokal
}

\author{
Sabaruddin Yunis Bangun*, Irawan Syahputra \\ Universitas Negeri Medan. Jalan Willem Iskandar/Pasar V, Medan, 20221, Indonesia \\ * Corresponding Author. Email: unisbgn@unimed.ac.id, syahputrairawan5@gmail.com
}

\begin{abstract}
Abstrak
Penelitian ini bertujuan untuk mengetahui peningkatan proses hasil belajar tolak peluru melalui penerapan strategi pembelajaran resiprokal pada siswa kelas XII MAN 2 Model Medan Tahun 2017. Penelitian ini dilakukan pada peserta didik kelas XII IPA1 yang menjadi subjek dengan jumlah siswa sebanyak 36 orang. Metode yang dipakai pada penelitian ini adalah Penelitian Tindakan Kelas. Indikator keberhasilan penelitian adalah penerapan strategi pembelajaran resiprokal sesuai dengan sintaks yang diacu. Dari hasil analisis data juga dapat diketahui bahwa hasil belajar peserta didik dari tes awal dan tes hasil belajar I masih rendah. Maka perlu dilakukannya perbaikan tindakan untuk siklus II. Di siklus II guru lebih meningkatkan dan memotivasi untuk lebih aktif dalam pengulangan pada tahap pelaksanaan dan follow trough nya. Penelitian menyimpulkan: Pada siklus I, dari 36 orang peserta didik terdapat 20 orang peserta didik $(55,5 \%)$ yang telah mencapai ketuntasan belajar, sedangkan 16 orang peserta didik $(44,5 \%)$ belum mencapai ketuntasan dalam belajar. Dengan nilai rata-rata hasil belajar peserta didik adalah 61,1 . Sedangkan pada siklus II dapat dilihat bahwa kemampuan peserta didik dalam melakukan tes hasil belajar siklus II secara klasikal sudah meningkat. Dari 36 orang peserta didik terdapat 33 orang $(91,6 \%)$ yang telah mencapai ketuntasan dalam belajar, sedangkan 3 orang peserta didik $(8,4 \%)$ belum mencapai ketuntasan dalam belajar. Dengan nilai rata-rata hasil belajar peserta didik adalah 71,25 .
\end{abstract}

Kata Kunci: tolak peluru, strategi pembelajaran, resiprokal

\section{Improved learning outcomes shot put through the application of reciprocal learning strategies}

\begin{abstract}
This study aims to determine the improvement of the shot put learning process through the application of reciprocal learning strategies to students of class XII MAN 2 Model Medan in 2017. This research was conducted on students of class XII IPA1 with a total of 36 students. The method used in this study is Class Action Research. The indicator of the success of the study is the application of reciprocal learning strategies in accordance with the syntax referred to. From the results of data analysis, it can also be seen that the learning outcomes of students from the initial test and the learning result test is still low. Then it is necessary to improve actions for the cycle II. The cycle II teachers improve and motivate them to be more active in repetition at the implementation stage and follow through. The study concluded: In the first cycle, 36 students there were 20 students $(55.5 \%)$ who had achieved mastery learning, while 16 students $(44.5 \%)$ had not achieved mastery in learning. With the average value of student learning outcomes is 61.1. Whereas in the second cycle it can be seen that the ability of students to test learning outcomes in the second cycle, classically has increased. Of the 36 students, there were 33 people $(91.6 \%)$ who had achieved mastery in learning, while 3 students $(8.4 \%)$ had not achieved mastery in learning. With the average value of student learning outcomes is 71.25 .
\end{abstract}

Keywords: shot put, learning strategies, reciprocal 


\section{Jurnal Pendidikan Jasmani Indonesia, 13 (2), 2017 - 66}

Sabaruddin Yunis Bangun, Irawan Syahputra

\section{PENDAHULUAN}

Pendidikan pada dasarnya adalah usaha sadar yang menumbuh kembangkan potensi sumber daya manusia peserta didik dengan cara mendorong dan memfasilitasi kegiatan belajr mereka. Pendidikan berfungsi membantu peserta dalam pengembangan dirinya, yaitu pengembangan semua potensi, kecakapan serta karakteristik pribadinya kearah yang positif, baik bagi dirinya maupun di lingkungannya.

Pada hakikatnya pendidikan jasmani adalah suatu hal yang memanfaatkan alat fisik untuk mengembangan keutuhan manusia. Dalam kaitan ini diartikan bahwa melalui fisik, aspek mental dan emosional pun turut terkembangkan, bahkan dengan penekanan yang cukup dalam. Berbeda dengan bidang lain, misalnya pendidikan moral, yang penekanannya benar-benar pada perkembangan moral, tetapi aspek fisik tidak turut terkembangkan, baik langsung maupun secara tidak langsung.

Menurut Djamarah dan Aswan dalam Dimyati dan Mudjiono (2002) belajar pada hakekatnya adalah "perubahan" yang terjadi di dalam diri seseorang setelah barakhirnya aktivitas belajar, aktivitas dalam kegiatan belajar tidak lain adalah untuk mengkonstruksi pengetahuan dan pemahan atas pengalaman dala kegiatan belajar mereka. Melalui aktivitas, seseorang peserta didik akan dapat memahami pelajaran dari pengalamannya sehingga akan mempertinggi hasil belajarnya.

Berdasarkan pernyataan di atas dapat disimpulkan bahwa aktivitas peserta didik dalam proses pembelajaran sagat penting. Hasil observasi yang saya lakukan mulai tanggal 21 sampai 24 maret 2016 di MAN 2 MODEL MEDAN pada kelas XII IPA-1 secara umum peserta didik memiliki kemampuan menengah kebawah. Pada kelas XII IPA-1 dari hasil observasi yang dilakukan yaitu peserta didik kurang berminat mengikuti pembelajaran dengan metode yang digunakan guru. Masih tampak beberapa yang kurang peduli dengan belajarnya sendiri, mengantuk, malas-malasan mengerjakan tugas yang diberikan. Sebagian besar peserta didik mengeluh dan merasa tidak mampu mengerjakan tugas yang diberikan. Dari jumlah peserta didik kelas XII IPA-1 sebanyak 36 orang, hanya 10 orang $(27,7 \%)$ yang bisa melakukan tolak peluru dengan benar. Dan 26 orang $(72,3 \%)$ yang masih belum bisa melakukan gerakan teknik tolak peluru dengan benar.Peneliti melihat peserta didik kurang terlibat dengan cara tahap pelaksanaan model atau metode pembelajaran, atau peserta didik merasa bosan, agar peserta didik dapat memahami materi yang diajarkan, guru harus mempergunakan metode pembelajaran yang dapat menarik kemauan peserta didik dalam belajar dan dapat meningkatkan hasil belajarnya. Melihat data aktivitas peserta didik dalam proses pembelajaran tersebut jelas mengindikasikan adanya permasalahan dalam kegiatan pembelajaran yang harus dicarikan pemecahannya.

Menerapkan metode resiprokal sebagai strategi pembelajaran sangat cocok untuk meningkatkan hasil belajar peserta didik, minat atau partisipasi peserta didik dalam mengikuti proses pembelajaran, menciptakan suasana pembelajaran yang menyenangkan dan tidak membosankan. Metode pembelajaran timbal balik (resiprokal) adalah sebuah metode pembelajaran pada kelompok-kelompok kecil yang didasarkan pada perumusan pertanyaan; melalui pengajaran dan pemberian contoh. Pada gaya ini, peserta didik bekerja dengan temannya dan memberikan umpan balik kepada temannya itu, berdasarkan kriteria yang ditentukan oleh guru.

Gaya mengajar resiprokal menekankan pada peserta didik untuk bekerja didalam suatu kelompok yang dibentuk hingga setiap anggotanya dapat berkomunikasi dengan nyaman dalam menyampaikan pendapat ataupun bertanya dalam rangka bertukar pengalaman keberhasilan belajar satu dengan yang lainnya.

Inti kegiatan dari gaya resiprokal ini adalah umpan timbal - balik. Melalui metode ini diharapkan peserta didik diharapkan hasil belajarnya dapat meningkat.Conbach dalam Suryabrata (2002) mengatakan bahwa "Belajar yang sebaik-baiknya adalah dengan mengalami dan dalam mengalami itu sipelajar menggunakan panca inderanya". Gagne dalam Dimyati dan Mudjiono (2009) mengatakan bahwa "Belajar dapat didefenisikan suatu proses dimana suatu organism perubahan perilakunya sebagai akibat pengalaman". 


\section{Jurnal Pendidikan Jasmani Indonesia, 13 (2), 2017 - 67}

Sabaruddin Yunis Bangun, Irawan Syahputra

Hasil belajar memacu pada terjadinya perubahan tingkah laku pada diri siswa yang dapat diamati dan diukur dalam bentuk perubahan pengetahuan, sikap dan keterampilan. Hasil belajar merupakan indicator untuk mengukur tingkat keberhasilan siswa dalam proses belajar mengajar. Indikator keberhasilan sebagai alat ukur untuk mengetahui tingkat keberhasilan siswa dalam melakukan tindakan belajar.

Menurut Sudjana (2009: 3) "penilaian hasil belajar adalah proses pemberian nilai terhadap hasil-hasil belajar yang dicapai siswa dengan kriteria tertentu". Hal ini mengisyaratkan bahwa objek yang dinilainya adalah hasil belajar siswa. Hasil belajar siswa pada hakikat nya adalah perubahan tingkah laku. Tingkah laku sebagai hasil belajar dalam pengertian yang luas mencakup bidang kognitif, efektif dan psikomotoris.

Proses belajar dapat dikatakan efektif bila ada perubahan yang terjadi pada diri siswa setidak tidaknya mencapai tingkat optimal dan efisien dan terletak pada kecepatan dan dikuasinya materi pelajaran yang disajikan, sekalipun dalam waktu yang relatif pendek. Dengan demikian jika gaya dan strategi yang dipilih itu tepat, maka aktifitas proses pembelajaran itu akan produktif,yaitu memberikan hasil yang baik. Oleh sebab itu, penilaian hasil belajar dan proses pembelajaran saling berkaitan satu sama lain sebab hasil merupkan akibat dari proses.

Sutikno (2000, p. 3) mengemukakan bahwa faktor-faktor yang mempengaruhi proses belajar siswa untuk berhasil ada dua yaitu:

Faktor internal yang berasal dari dalam diri siswa itu sendiri, meliputi faktor jasmaniah, (kesehatan, cacat tubuh), faktor psikologis, (intelegasi, perhatian, minat, bakat, motif, kematangan dan kesiapan), dan kelelahan. Faktor eksternal yang berasal dari luar peserta didik, meliputi: Keluarga (cara orang tua mendidik, hubungan antar keluarga, suasana rumah, keadaan ekonomi, pengertian orang tua dan latar belakang kebudayaan), Sekolah seperti gaya mengajar, relasi guru dengan peserta didik, kurikulum, relasi antara peserta didik, disiplin, alat pelajaran (media), keadaan gedung, metode belajar,dan tugas rumah). Dan Masyarakat (keadaan peserta didik dalam masyarakat, masyarakat media, teman bergaul, dan bentuk kehidupan masyarakat).

Berkaitan dengan faktor dari dalam diri peserta didik, selain faktor kemampuan, ada juga faktor lain yaitu motivasi, minat, perhatian, sikap, kebiasaan belajar akan memberikan andil yang cukup penting. Berhasil atau tidaknya seseorang dalam mencapai hasil belajar disebabkan dari faktor, baik yang berasal dari dalam diri peserta didik maupun yang berasal dari luar dirinya.

Dari penjelasan diatas dapat dikatakan bahwa hasil belajar adalah keseluruhan hasil yang diperoleh dari kegiatan berupa pengetahuan, keterampilan dan sikap yang mampu mengakibatkan perubahan tingkah laku, dimana hasil tersebut dilihat melalui suatu alat ukur yang dinamakan dengan evaluasi.

Hasil belajar adalah akibat dari proses belajar dengan menggunakan alat pengukur yaitu berupa tes yang disusun secara terencana, baik tes tertulis, tes lisan, maupun tes perbuatan (Sujana, 2001) dalam Wassid (2009, p. 128). Hasil belajar adalah hasil yang diperoleh siswa setelah mengikuti satu materi tertentu dan mata pelajaran yang berupa data kuantitatif dan kualitatif.

Tujuan penelitian ini adalah: Untuk mengetahui bagaimanakah peningkatan hasil belajar tolak peluru melalui penerapan strategi pembelajaran resiprokal pada siswa kelas XII MAN 2 Model Medan Tahun 2017.Penelitian ini diharapkan akan dapat bermanfaat untuk: 1) Secara praktis:Melalui penelitian ini diharapkan peserta didik dapat menyenangi dan mampu melakukan olahraga, khususnya dalam tolak peluru, Sebagai masukan dan pertimbangan bagi para guru pendidikan jasmani khususnya pada pokok bahasan tolak peluru dalam meningkatkan mutu hasil pembelajaran tolak peluru melalui strategi pembelajaran resiprokal, Sebagai masukan kepada supervisi pendidikan (kepala sekolah) bahwasanya penilitian tindakan kelas merupakan salah satu cara yang dapat membuat proses pembelajaran berjalan secara efektif dan efisien. 2) Secara teoritis:Bagi peneliti untuk menambah wawasan ilmiah dan memperkaya ilmu pengetahuan pendidikan jasmani sekolah. 


\section{METODE}

Subjek dalam penelitian ini adalah siswa kelas XII IPA 1 MAN 2 Model Medan dengan jumlah 36 orang. Jenis penelitian ini adalah penelitian tindakan kelas yang memiliki empat tahapan yaitu: (1) Perencanaan, (2) Pelaksanaan, (3) Pengamatan, (4) Refleksi.Adapun instrument penelitian dalam penelitian ini adalah berupa lembar penilaian portofolio tes proses belajar I dan II. Tes proses belajar diberikan setelah pengajaran dengan menggunakan strategi pembelajaran resiprokal yang dilakukan. Dalam tes ini peserta didik diminta untuk melakukan rangkaian teknik tolak peluru gaya o'brien yaitu awalan, pelaksanaan, dan follow trough, dan peneliti menilai setiap proses pelaksanaan rangkaian teknik tolak peluru gaya o'brien yang dilakukan peserta didik. Analisa data dilakukan dengan 2 cara yaitu reduksi data guna untuk menyeleksi,menyederhanakan dan mentransformasikan data yang telah disajikan dalam transkip catatan lapangan dan memaparkan data berdasarkan lembar portofolio.

\section{HASIL DAN PEMBAHASAN}

Berikut ini adalah deskripsi data hasil penelitian yang dimulai dari tes siklus I, dan tes siklus II.

\section{Siklus I}

Pada tahap ini peneliti dan guru menyusun skenario pembelajaran yang terdiri dari beberapa tahap sebagai berikut: (1) Tim penelliti (guru penjas dan tim peneliti) melakukan analisis kurikulum untuk mengetahui kompetensi dasar yang akan disampaikan pada peserta didik dalam pembelajaran penjas; (2) Membuat rencana pembelajaran bersama guru penjas dengan mengacu pada tindakan yang diterapkan dalam PTK, yaitu pembelajaran tolak peluru gaya O'Brien atau membelakangi dengan menggunakan gaya mengajar resiprokal; (3) Menyiapkan media yang dibutuhkan untuk proses pembelajaran tolak peluru gaya O'Brien; dan (4) Membuat lembar observasi untuk melihat bagaimana kondisi belajar mengajar disekolah tempat penelitian dan membuat tes hasil belajar.

\section{Pelaksanaan Tindakan Siklus I}

Setelah perencanaan disusun maka selanjutnya dilakukan tindakan atau pelaksanaan terhadap kesulitan yang dialami peserta didik. Pada tahap ini peneliti membuat alternatif pemecahan masalah untuk mengatasi kesulitan yang dialamipeserta didik dan untuk meningkatkan hasil belajar tolak peluru gaya o'brien. Alternatif yang digunakan yaitu dengan menerapkan pembelajaran resiprokal untuk meningkatkan hasil belajar tolak peluru siswa pada kelas XII IPA-1MAN 2 Model Medan Tahun Ajaran 2017.

\section{Capaian Pembelajaran Tolak Peluru Gaya O’Brien}

Berdasarkan dari hasil observasi kegiatan pembelajaran siklus I, proses pembelajaran melalui penerapan model pembelajaran resiprokal yang dilakukan peneliti dan peserta didik telah mengalami peningkatan. Walaupun pada siklus I masih terlihat kebanyakan peserta didik belum tepat pada saat melakukan proses tolak peluru gaya o'brien. Jumlah keseluruhan yang diperoleh peserta didik pada saat melakukan sikap awalan adalah 101 dengan nilai rata-rata siswa 2,80, jumlah keseluruhan yang diperoleh peserta didik pada saat melakukan sikap pelaksanaan adalah 82 dengan nilai rata-rata peserta didik 2,27 , jumlah keseluruhan yang diperoleh siswa pada saat melakukan sikap akhir adalah 85 dengan nilai rata-rata siswa 2,36 dengan nilai persentase ketuntasan klasikal ( PKK) hasil belajar tolak peluru gaya o'brien yang diperoleh mencapai $55,5 \%$. Untuk mempermudah melihat dan memahami hasil belajar siswa pada siklus I dapat dilihat dari Tabel 1.

Tabel 1. Jumlah Skor Rata-Rata Siklus I

\begin{tabular}{ccccccc}
\hline \multirow{2}{*}{ No. } & \multirow{2}{*}{ Hasil Tes } & \multicolumn{3}{c}{ Aspek yang dinilai } & \multirow{2}{*}{ Jumlah } \\
\cline { 3 - 6 } & \multirow{2}{*}{ Siklus I } & $\Sigma$ & Fase Awalan & Fase Pelaksanaan & Fase Follow-through & \\
\hline \multirow{2}{*}{ 1. } & \multirow{2}{*}{ Sinl } & 2,80 & 82 & 85 & 268 \\
& & & & 2,27 & 2,36 & 7,4 \\
\hline
\end{tabular}


Dari data hasil belajar siklus I yang dapat dilihat bahwa kemampuan peserta didik dalam melakukan tes hasil belajar secara klasikal sudah meningkat dari 36 orang siswa ternyata sudah 20 orang siswa $(55,5 \%)$ yang mencapai ketuntasan belajar dan 16 orang $(44,5 \%)$ yang belum mencapai ketuntasan belajar. Nilai rata-rata kelas yang diperoleh telah mencapai 7,4 (Tuntas).

\section{Refleksi Siklus I}

Berdasarkan hasil pengamatan pada siklus I, peneliti masih perlu memberikan motivasi dan penguatan kepada peserta didik untuk mendukung terlaksananya program pembelajaran dengan baik. Pada pelaksanaan kegiatan, pesertra didik masih mengalami kesulitan dalam melakukan gerakan-gerakan tolak peluru gaya O'Brien. Peserta didik masih perlu menyesuaikan diri terhadap penerimaan penilaian teman. Peserta didik masih memerlukan tambahan waktu dalam menguasai teknik dasar tolak peluru gaya O'Brien. Kesulitan peserta didik tersebut lebih banyak terdapat pada tahap kedua dan ketiga yaitu tahap pelaksanaan dan tahap follow-through.

Adapun kesulitan-kesulitan dalam pelaksanaan tindakan siklus I dapat diuraikan sebagai berikut: Pertama, Pada penilaian portofolio tahap pelaksanaan peserta didik masih banyak melakukan kesalahan pada saat memutarkan tubuh ke depan. Peserta didik tidak memutarkan pinggang dahulu sehingga kesimbangan kurang. Padatahap follow-through kebanyakan peserta didik setelah menolakkan peluru, peserta didik tidak memindahkan kaki yang bertumpu pada saat di awalan menjadi kedepan sehingga follow-through tidak kelihatan. Kedua, Peserta didik masih kurang memahami yang disampaikan/dikoreksi teman sehingga pada saat proses pelaksanaan banyak peserta didik yang bingung untuk melakukan tahap pelaksanaan dan follow-trough.

Berdasarkan hasil refleksi pada siklus I tersebut, maka perlu melakukan tindakan untuk mengatasinya berupa penekanan penjelasan materi dengan menambah variasi pembelajaran agar peserta didik lebih paham cara pelaksanaannya tersebut, sehingga seluruh peserta didik dapat melakukannya dengan baik.

Tabel 2. Hasil Tes Siklus I (post test I) Tolak Peluru Gaya O'Brien

\begin{tabular}{|c|c|c|}
\hline Hasil Tes & Jumlah Siswa & Persentase (\%) \\
\hline Tuntas & 20 & 55,5 \\
\hline Tidak Tuntas & 10 & 44,5 \\
\hline
\end{tabular}

Berikut pelaksanaan siklus II, dimulai dari tahap perencanaan, pelaksanaan tindakan, observasi dan refleksi.

Pada tahap ini peneliti dan guru menyusun skenario pembelajaran yang terdiri dari beberapa tahap sebagai berikut: (1) Tim penelliti (guru penjas, peneliti dan mitra kerja) melakukan analisis kurikulum untuk mengetahui kompetensi dasar yang akan disampaikan pada peserta didik dalam pembelajaran penjas; (2) Membuat rencana pembelajaran bersama guru penjas dengan mengacu pada tindakan yang diterapkan dalam PTK, yaitu pembelajaran tolak peluru gaya o'brien dengan menggunakan gaya mengajar resiprokal; (3) Menyiapkan media yang dibutuhkan untuk proses pembelajaran tolak peluru gaya O'brien; (4) Membuat lembar observasi untuk mellihat bagaimana kondisi belajar mengajar disekolah tempat penelitian dan membuat tes hasil belajar.

Pelaksanaan siklus II

Setelah perencanaan disusun secara baik maka dilakukan tindakan terhadap kesulitan peserta didik pada siklus I yang telah dilaksanakan sebelumnya. Adapun pelaksanaan tindakan siklus II adalah sebagai berikut:

Pertama, peserta didik dikumpulkan dilapangan, dibariskan dan diarahkan untuk melakukan pemanasan oleh guru penjas. Setelah selesai melakukan pemanasan, guru penjas menjelaskan bagian inti dari pelaksanaan tolak peluru gaya o'brien mulai dari tahap awalan, tahap pelaksanaan dan tahap follow-through. Pada tahap berikutnya guru penjas menjelaskan variasi pembelajaran tolak peluru gaya o'brien serta teknik pelaksanaannya yang akan dilaksanakan pada proses pembelajaran, yaitu dimulai dari variasi melakukan gerakan 
menolak peluru gaya o'brien dengan dibantu temannya dengan memegang tangan peserta didik yang akan melakukannya, peserta didik dikumpulkan dengan membentuk kelompok.

Kedua, setelah pelaksanaan pembelajaran telah selesai maka peserta didik diarahkan untuk melakukan tes tolak peluru gaya o'brien dan sambil dilakukan pengambilan data untuk melihat apakah ada peran pemanfaatan dari pembelajaran yang telah dilakukan terhadap peningkatan hasil belajar tolak peluru gaya o'brien pada siswa, khususnya peningkatan pemahaman peserta didik mengenai teknik dasar tolak peluru gaya O'brien. Dan ketiga, Peserta didik melakukan pendinginan dan guru menyimpulkan hasil diskusi peserta didik dan menutup pembelajaran.

\section{Hasil Observasi Kegiatan Pembelajaran Siklus II}

Pada tahap ini dilakukan observasi terhadap pelaksanaan tindakan yang dilakukan peneliti dan peserta didik menggunakan lembar observasi yang telah dibuat. Untuk mengamati proses pembelajaran yang dilakukan peneliti digunakan lembar observasi guru dan untuk mengamati proses partisipasi belajar peserta didik menggunakan lembar observasi. Sedangkan untuk menilai hasil belajar tolak peluru peserta didik digunakan lembar penilaian porofolio.

Setelah pengamatan yang dilakukan pada guru dan peserta didik selanjutnya dilakukan pengamatan melalui hasil pembelajaran yang telah dilaksanakan atau pengamatan hasil belajartolak peluru gaya o'brien pada siklus II yang terlampir pada Tabel 3:

Tabel 3. Jumlah Skor dan Rata-Rata Siklus II

\begin{tabular}{ccccccc}
\hline \multirow{2}{*}{ No. } & \multirow{2}{*}{ Hasil Tes } & \multicolumn{4}{c}{ Aspek yang dinilai } & \multirow{2}{*}{ Jumlah } \\
\cline { 3 - 6 } & & Fase Awalan & Fase Pelaksanaan & Fase Follow-through & \\
\hline \multirow{2}{*}{ 1. Siklus II } & $\Sigma$ & 121 & 95 & 90 & 305 \\
& \multirow{2}{*}{} & 3.36 & 2.63 & 2.5 & 8,47 \\
\hline
\end{tabular}

Refleksi Siklus II

Berdasarkan hasil observasi pada siklus II, proses belajar mengajar sudah berjalan lebih baik dibandingkan dengan pembelajaran pada siklus I. jika pada siklus I ketuntasan klasikal peserta didik secara keseluruhan hanya mencapai $55,5 \%$, maka pada siklus II ketuntasan klasikal peserta didik keseluruhan meningkat menjadi 91,6\%.

Dari data hasil belajar siklus II yang dapat dilihat bahwa kemampuan peserta didik dalam melakukan tes hasil belajar secara klasikal sudah meningkat dari 36 orang siswa ternyata sudah 33 orang siswa $(91,6 \%)$ yang mencapai ketuntasan belajar, hanya 3 orang siswa $(8,4 \%)$ yang belum mencapai ketuntasan belajar. Nilai rata-rata kelas yang diperoleh telah mencapai 71,25 (Tuntas).

Hasil refleksi peneliti, adapun ditemukannya permasalahan pada siklus II adalah: (1) Pada indikator 2 memutar tubuh, masih ada peserta didik yang tidak menolakkan kaki sehingga tidak mendapatkan gaya dan melakukan tolakan dengan maksimal; (2) Masih ada peserta didik yang belum mampu memutarkan pinggang/pinggulnya dahulu pada saat mau memutarkan tubuh ke depan. Dan (3) Sebagian besar peserta didik sudah mampu menguasai teknik dasar tolak peluru gaya o'brien dengan baik.

Berdasarkan deskripsi data penelitian, maka pada penelitian ini diperoleh hasil sebagai berikut: Pertama, Setelah pemberian tindakan pada siklus I sebanyak satu kali pertemuan, peserta didik diberikan tes hasil belajar I yang kemudian diperoleh sebanyak 20 orang peserta didik $(55,5 \%)$ yang telah mencapai ketuntasan belajar, sedangkan 16 orang peserta didik $(44,5 \%)$ lainnya belum mencapai tingkat ketuntasan belajar yang diharapkan. Dengan kesulitan (1) Pada penilaian portofolio tahap pelaksanaan peserta didik masih banyak melakukan kesalahan pada saat memutar tubuh,peserta didik tidak menolakkan kaki sehingga gaya dan tolakan kurang maksimal. Pada tahap follow-through kebanyakan peserta didik setelah menolakkan peluru tidak memutarkan kaki yang menumpu untuk berpindah kedepan sehingga follow-through tidak kelihatan.

Kedua, Kemudian setelah diberikan tindakan pada siklus II sebanyak satu kali pertemuan, siswa kembali diberi tes hasil belajar II yang kemudian diperoleh sebanyak 33 


\section{Jurnal Pendidikan Jasmani Indonesia, 13 (2), 2017 - 71}

Sabaruddin Yunis Bangun, Irawan Syahputra

orang peserta didik $(91,6 \%)$ telah mencapai ketuntasan belajar dan 3 orang peserta didik $(8,4 \%)$ yang belum mencapai ketuntasan dalam belajar. Dan peserta didik yang belum tuntas ini sebagian besar adalah peserta didik dengan kesulitan memutarkan pinggang/pinggul dan menolakkan sehingga hasil gayanya kurang maksimal.

Ketiga, Dari hasil penelitian diperoleh rata-rata nilai hasil belajar peserta didik pada siklus II adalah 71,25 dengan tingkat ketuntasan belajar secara klasikal sebesar 91,6\%. Ini berarti terlihat ada peningkatan dari siklus I dan siklus II.

\section{SIMPULAN}

Berdasarkan temuan dan hasil pembahasan peneliti, hasil belajar peserta didik pada siklus I setelah diberikan strategi pembelajaran resiprokal tes hasil belajar I dapat dilihat bahwa kemampuan awal peserta didik dalam melakukan teknik dasar tolak peluru gaya o'brien masih rendah. Dari 36 orang siswa terdapat 20 orang peserta didik $(55,5 \%)$ yang telah mencapai ketuntasan belajar, sedangkan 16 orang peserta didik $(44,5 \%)$ belum mencapai ketuntasan dalam belajar. Dengan nilai rata-rata hasil belajar peserta didik adalah 61,1.

Sedangkan pada siklus II dapat dilihat bahwa kemampuan peserta didik dalam melakukan tes hasil belajar siklus II secara klasikal sudah meningkat. Dari 36 orang peserta didik terdapat 33 orang $(91,6 \%)$ yang telah mencapai ketuntasan dalam belajar, sedangkan 3 orang peserta didik $(8,4 \%)$ belum mencapai ketuntasan dalam belajar. Dengan nilai rata-rata hasil belajar peserta didik adalah71,25. Berdasarkan hal itu maka dapat ditarik kesimpulan bahwa melalui penerapan strategi pembelajaran resiprokal dapat meningkatkan hasil belajar tolak peluru pada kelas XII IPA-1 MAN 2 Model Medan Tahun 2017.

\section{DAFTAR PUSTAKA}

Djamarah, \& Aswan, (2002). Strategi belajar mengajar. Jakarta: Rineka Cipta.

Suryabrata, S. (2002). Psikologi pendidikan. Jakarta : PT. Raja Grafindi Persada.

Dimyati, \& Mudjiono, (2009). Belajar dan pembelajaran. Jakarta : Rineka.

Sudjana, N. (2009). Penilaian hasil proses belajar mengajar. Bandung: PT. Remaja Rosdakarya.

Sutikno, S. (2000). Belajar dan pembelajaran.Bandung: Prospect. 